\title{
Access to antibiotics: a safety and equity challenge for the next decade
}

\author{
Jean Carlet $^{1,2^{*}}$ and Didier Pittet ${ }^{3}$
}

\begin{abstract}
Bacterial resistance to antibiotics is increasing worldwide in healthcare settings and in the community. Some microbial pathogens have become resistant to multiple antibiotics, if not all presently available, thus severely compromising treatment success and contributing to enhanced morbidity, mortality, and resource use. The major driver of resistance is misuse of antibiotics in both human and non-human medicine. Both enhanced access and restricted use in many parts of the world is mandatory. There is an urgent need for an international, integrated, multi-level action to preserve antibiotics in the armamentarium of the $21^{\text {st }}$ century and address the global issue of antimicrobial resistance.
\end{abstract}

Keywords: Antibiotics, Antimicrobial resistance, Antimicrobial resistance surveillance, Antibiotics - use, Multidrugresistant organisms

\section{Background}

Antibiotics are one of the most important discoveries in medicine and have saved millions of lives. The current paradoxical scandal is that although most resourcelimited countries still lack easy access to antibiotics, their overuse and abuse is rife in developed nations and the cause of accelerating rates of resistance development. A global two-pronged approach is urgently needed to promote facilitated access and to alert the scientific and lay community to the dangers of misuse, potentially leading to a severe lack of therapeutic agents to treat infections in the near future.

Access to antibiotics is a major concern in many countries worldwide [1-4]. Reasons include the very low economic status of a large number of nations, inappropriate use, the high cost of the most recent and efficacious antibiotics, extensive "over the counter" usage, an increasing number of counterfeit drugs, and a dramatic increase in antimicrobial resistance (AMR). Importantly, countries with only a few antibiotics available and a high number of deaths from infection are not protected from antibiotic resistance $[5,6]$. Great strides have been made towards the

\footnotetext{
* Correspondence: jeancarlet@gmail.com

${ }^{1}$ World Alliance Against Antibiotic Resistance (WAAR), 9 rue de la Terrasse, 94000 Creteil, France

${ }^{2}$ Hôpital St Joseph, 185 rue Raymond Losserand, 75014, Paris, France

Full list of author information is available at the end of the article
}

eradication of some pandemic infections, such as malaria, tuberculosis, and human immunodeficiency virus (HIV)/ acquired immunodeficiency syndrome (AIDS), in particular due to the generous support of the Global Fund, UNITAID, The Bill \& Melinda Gates Foundation, and other large international funding organizations. However, infections due to common microorganisms responsible for more widely-spread diseases still represent an extremely high overall burden worldwide, such as pneumonia, gastrointestinal infections, and meningitis.

\section{Resistance in healthcare}

Antibiotic resistance in healthcare facilities is a very serious concern in most developed and developing nations. Only a few Scandinavian countries and the Netherlands have had the strategic vision to limit the invasion of their country by resistant strains through the implementation of very active programmes. Somewhat ironically, some bacteria, particularly Gram-negatives, are now resistant to almost every available antibiotic, including the most recent generation [7]. Some are still susceptible to colistin, a 50-year-old and rather toxic compound, almost forgotten until recently or only used in resourcelimited countries [8]. Late-onset ventilator-associated pneumonia is treated empirically with colistin in the intensive care units of several countries but, unfortunately, Pseudomonas aeruginosa and Acinetobacter spp.

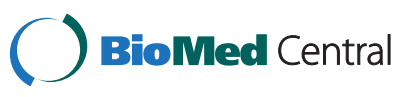

(C) 2013 Carlet and Pittet; licensee BioMed Central Ltd. This is an Open Access article distributed under the terms of the Creative Commons Attribution License (http://creativecommons.org/licenses/by/2.0), which permits unrestricted use, distribution, and reproduction in any medium, provided the original work is properly cited. 
resistance has been described [9]. The worst case scenario for the future is that an unknown number of patients might die because active antibiotics are no longer available. This is unacceptable, although far less unacceptable than the lack of access to antibiotics in many countries.

\section{Community-acquired resistance}

Resistance to antibiotics in the community is an emerging problem in developed and developing countries and possibly even more frightening. The best examples are community- acquired methicillin-resistant Staphylococcus aureus (MRSA), particularly in the USA [10], Escherichia coli or Klebsiella pneumonia-producing extended-spectrum beta-lactamases (ESBL) [11] and, more recently, carbapenemases [12]. The risk is that carbapenems could replace cephalosporins or broad-spectrum penicillins for the empiric treatment of community-acquired diseases, such as pyelonephritis or intra-abdominal infections, where our lifelong "partners", enterobacteriacae, are involved. Carbapenems are the main antibiotics that remain efficient for the treatment of hospital-acquired ESBL infections and represent our last line of defence in many regards. Many carbapenemases have already been described, notably in E. coli and $K$. pneumonia [12], and this class of antibiotics is in real danger and must be protected. To achieve this, carbapenem use must be regulated and restricted to severe infections treated with specialist input or in consultation with a clinical infectious diseases' specialist. Combinations of betalactams with beta-lactamases inhibitors are likely to be helpful in the future [13,14].

We have available a good list of new compounds highly active against Gram-positive bacteria, but only very few active against multi-resistant Gram-negatives in the pipeline. This constitutes a critical safety issue worldwide and is certainly far more important in terms of potential impact than the H1N1 influenza pandemic (25,000 versus 14,000, respectively, in Europe in 2009) [15,16]. The reality is that both short- and long-term international reactions to such a threat have been too weak and too slow. We have been unable or unwilling to modify global behaviour towards antibiotic use, thus preparing a very dark future for generations to come.

\section{Rethinking current clinical practice}

In the critically ill, particularly for septic shock, recent international guidelines strongly encourage clinicians to start broad spectrum antibiotics immediately, if possible within the first hour of admission [17]. In many institutions, delaying the start of antibiotics to treat communityacquired pneumonia is considered as an indicator of poor quality of care. Such measures make sense and possibly save lives [18]. However, the use of such indicators and the desire to meet required targets may have unintended consequences or harm. Therefore, clinicians should ensure that the diagnosis is robust to prevent unnecessary treatment with broad spectrum antibiotics. All treatment should be subject to review after two or three days and new antibiotics should require the prior input of an infection specialist [19]. In many cases, antibiotics can be stopped at days two or three or changed to narrower spectrum compounds. If combination therapy has been used empirically, subsequent reversion to monotherapy is possible in most cases. The term "de-escalation" is sometimes used to describe such a strategy, but there are two prerequisites for success. First, clinicians and microbiologists must be encouraged to obtain appropriate microbiological samples before starting empiric therapy to streamline the antibiotic strategy, particularly in the critically ill. Second, clinicians need to feel comfortable about the decision to de-escalate, even when initial therapy was effective. The motto "don't change a winning team" is certainly not applicable to antibiotic therapy. Microorganisms represent very special therapeutic targets - a living and respectful target. Similar to many antibiotics, bacteria have been present in the environment long before man and due respect is essential, at least from an ecological standpoint.

In some European countries, physicians feel at ease to change initial empiric antibiotic therapy even when it works, thus following recommendations issued in recently published guidelines [20]. Prescribers need help, not blame. National guidelines have been elaborated over the past few years [21,22], including for veterinary medicine [23], as well as many reports on the prevention of AMR spread [21,24,25]. However, since the report of an international task force meeting in 1995 [26], no truly coordinated, international efforts have been made to tackle the global issue of AMR and access to antibiotics, apart from specific diseases such as malaria, tuberculosis, and HIV/AIDS.

\section{Developing a collective conscience}

Limiting antibiotic consumption comprises a certain degree of risk. Some diseases, such as post-streptococcal infections could reappear. Some infections, like meningitis, might be more frequent if patients with high fever are no longer treated with antibiotics. Risks must be evaluated, carefully followed, and balanced against the risk of resistance. National public health agencies and international organizations, such as the World Health Organization (WHO), must assume their responsibility and give clear recommendations, while taking such risks into account. There are additional philosophical and ecological reasons to focus on equity and access to antibiotics. Most antibiotics, like animals and plants, are natural products belonging to "mother nature" and humanity. Part of our collective ecological and moral duty is not only to protect them, but also to make them 
available to every human being. Equity is an integral part of quality and safety [27].

AMR is considered an extremely serious issue by the WHO Patient Safety programme. Its recent publication entitled "The evolving threat of antimicrobial resistance options for action" [28] examines the experiences of governments and health facilities/providers with implementing some of the recommendations of the 2001 WHO Global Strategy for Containment of Antimicrobial Resistance. It reflects upon lessons learned during the past decade and remaining gaps, while drawing attention to areas where knowledge is still lacking and urgent action needed. One of the programme strands, African Partnerships for Patient Safety, includes the prevention of healthcare-associated infections and access to antimicrobials as it is clearly established that developing countries have very high rates of nosocomial infections and AMR [5]. The precise burden of non-access to antibiotics is unknown and these data are urgently needed. If we do not undertake this global, international, integrated action now, future generations will certainly never forgive us for having been so weak and passive to meet this challenge.

\section{Competing interests}

The authors declare that they have no competing interests.

\section{Authors' contributions}

$J C$ and DP contributed equally to the concept, drafting and critical revision of the manuscript. Both authors approved the final version submitted for publication.

\section{Author details}

'World Alliance Against Antibiotic Resistance (WAAR), 9 rue de la Terrasse, 94000 Creteil, France. ${ }^{2}$ Hôpital St Joseph, 185 rue Raymond Losserand, 75014, Paris, France. ${ }^{3}$ Infection Control Programme and WHO Collaboration Centre on Patient Safety, University of Geneva Hospitals and Faculty of Medicine, 4 Rue Gabrielle Perret-Gentil, Geneva, Switzerland.

Received: 16 July 2012 Accepted: 6 January 2013

Published: 10 January 2013

\section{References}

1. Carlet J, Collignon P, Goldmann D, Goossens H, Gyssens IC, Harbarth S, Jarlier V, Levy SB, N'Doye B, Pittet D, Richtmann R, Seto WHO, Van der Meer JWM, Voss A: Society's failure to protect a precious resource: antibiotics. Lancet 2011, 378(9788):369-371.

2. Hughes JM: Preserving the lifesaving power of antimicrobial agents. JAMA 2011, 305(10):1027-1028.

3. Piddock $L$ : The crisis of no new antibiotics-what is the way forward. Lancet Infect Dis 2012, 12(3):249-253.

4. Bush K, Courvalin P, Gautam D, Bush K, Courvalin P, Dantas G, Davies J, Eisenstein B, Huovinen P, Jacoby GA, Kishony R, Kreiswirth BN, Kutter E, Lerner SA, Levy S, Lewis K, Lomovskaya O, Miller JH, Mobashery S, Piddock L, Projan S, Thomas CM, Tomasz A, Tulkens PM, Walsh TR, Watson JD, Witkowski J, Witte W, Wright G, Yeh P, Zgurskaya HI: Tackling antibiotic resistance. Nat Rev Microbiol 2011, 9(12):894-895.

5. Allegranzi B, Bagheri-Nejad S, Combescure C, Graafmans W, Attar H, Donaldson L, Pittet D: Burden of endemic healthcare-associated infection in developing countries: systematic review and meta-analysis. Lancet 2011, 377(9761):228-241.

6. Vlieghe E: The First Global Forum on Bacterial Infections calls for urgent action to contain antibiotic resistance. Expert Rev Anti Infect Ther 2012, 10(12):145-148.
7. Rossolini GM, Mantengoli E, Docquier JD, Musmanno RA, Coratza G: Epidemiology of infections caused by multiresistant gram-negatives: ESBLs, MBLs, panresistant strains. New Microbiol 2007, 30(2):332-339.

8. Carlet J, Mainardi $\mathrm{J}$ : Antibacterial agents: back to the future. Can we live with only colistin, co-trimoxazole, and fosfomycin. Clin Microbiol Infect 2012, 18(1):1-3.

9. Matthaiou DK, Michalopoulos A, Rafailidis PI, Karageorgopoulos DE, Papaioannou V, Ntani G, Samonis G, Falagas ME: Risk factors associated with the isolation of colistin-resistant gram-negative bacteria: a matched case-control study. Crit Care Med 2008, 36(3):807-811.

10. Deleo FR, Otto M, Kreiswirth BN, Chambers HF: Community-associated meticillin-resistant Staphylococcus aureus. Lancet 2010, 375(9725):1557-1568.

11. Meir S, Weber R, Zbinden R, Ruef C, Hasse B: Extended-spectrum betalactamases producing Gram-negative pathogens in community-acquired urinary tract infections: an increasing challenge for antimicrobial therapy. Infection 2011, 39(4):333-340.

12. Kumarasamy KK, Toleman MA, Walsh TR: Emergence of a new antibiotic resistance mechanism in India, Pakistan, and the UK: a molecular, biological, and epidemiological study. Lancet Infect Dis 2010, 10(9):597-602.

13. Perez F, Bonomo RA: Can we really use beta-lactam/beta-lactam inhibitor combinations for the treatment of infections caused by extended-spectrum beta-lactamase-producing bacteria. Clin Infect Dis 2012, 54(2):175-177.

14. Bassetti M, Ginocchio F, Mikulska M, Taramasso L, Giacobbe DR: Will new antimicrobials overcome resistance among Gram-negatives. Expert Rev Anti Infect Ther 2011, 9(10):909-922.

15. European Centre for Disease Prevention and Control (ECDC) and European Medicines Agency (EMEA): ECDC/EMEA joint technical paper: the bacterial challenge, time to react. Stockholm, Sweden: 2009. http://www.ecdc.europa.eu/ en/publications/Publications/0909_TER_The_Bacterial_Challenge_Time_to_React. pdf; accessed December 14, 2012

16. European Centre for Disease Prevention and Control: ECDC daily update. 2009 influenza A (h1N1) pandemic: 2010. http://ecdc.europa.eu/en/healthtopics/ Documents/100119_Influenza_AH1N1_Situation_Report_0900hrs.pdf; accessed December 17, 2012.

17. Dellinger RP, Levy MM, Carlet JM, Bion J, Parker MM, Jaeschke R, Reinhart K, Angus DC, Brun-Buisson C, Beale R, Calandra T, Dhainaut JF, Gerlach H, Harvey M, Marini JJ, Marshall J, Ranieri M, Ramsay G, Sevransky J, Thompson BT, Townsend S, Vender JS, Zimmerman JL, Vincent JL, International Surviving Sepsis Campaign Guidelines Committee; American Association of Critical-Care Nurses; American College of Chest Physicians; American College of Emergency Physicians; Canadian Critical Care Society; European Society of Clinical Microbiology and Infectious Diseases; European Society of Intensive Care Medicine; European Respiratory Society; International Sepsis Forum; Japanese Association for Acute Medicine; Japanese Society of Intensive Care Medicine; Society of Critical Care Medicine; Society of Hospital Medicine; Surgical Infection Society; World Federation of Societies of Intensive and Critical Care Medicine: Surviving Sepsis Campaign: international guidelines for management of severe sepsis and septic shock: 2008. Crit Care Med 2008, 36(1):296-327.

18. Levy MM, Dellinger PR, Townsend SR, Linde-Zwirble WT, Marshall JC, Bion J, Bion J, Schorr C, Artigas A, Ramsay G, Beale R, Parker MM, Gerlach H, Reinhart K, Silva E, Harvey M, Regan S, Angus DC, Surviving Sepsis Campaign: The Surviving Sepsis Campaign: results of an international guideline-guided performance improvement program targeting severe sepsis. Crit Care Med 2010, 38(2):67-74.

19. Van Gastel E, Costers M, Peetermans WE, Struelens MJ, Hospital Medicine Working Group of the Belgian Antibiotic Policy Coordination Committee: Nationwide implementation of antibiotic management teams in Belgian hospitals: a self-reporting survey. J Antimicrob Chemother 2010, 65(3):576-580.

20. Antibiotic therapy and prevention of bacterial resistance in healthcare organisations: 2008. http://www.has-sante.fr/portail/upload/docs/application/pdf/ 2010-03/antibiotic_therapy_and_prevention_of_bacterial_resistance_-_guidelines. pdf; accessed December 14, 2012.

21. Loveday HP, Pellowe CM, Jones SR, Pratt RJ: A systematic review of the evidence for interventions for the prevention and control of meticillinresistant Staphylococcus aureus (1996-2004): report to the Joint MRSA Working Party (Subgroup A). J Hosp Infect 2006, 63(Suppl 1):S45-S70.

22. Ofner-Agostini $M$, Varia M, Johnston L, Green $K$, Simor A, Amihod B, Bryce E, Henderson E, Stegenga J, Bergeron F, Canadian Nosocomial Infection Surveillance Program, Gravel D: Infection control and antimicrobial 
resistance practices for antmicrobial-resistant organisms in Canadian tertiary care hospitals. Am J Infect Control 2007, 35(9):563-568.

23. Anthony F, Acar J, Franklin A, Gupta R, Nicholls T, Tamura Y, Thompson S, Threlfall EJ, Vose D, van Vuuren M, White DG, Office International des Epizooties Ad hoc Group: Antimicrobial resistance: responsible and prudent use of antimicrobial agents in veterinary medicine. Rev Sci Tech 2001, 20(3):829.

24. Wernitz MH, Swidsinski S, Weist K, Sohr D, Witte W, Franke KP, Roloff D, Rüden H, Veit SK: Effectiveness of a hospital-wide selective screening programme for methicillin-resistant Staphylococcus aureus (MRSA) carriers at hospital admission to prevent hospital-acquired MRSA infections. Clin Microbiol Infect 2005, 11(6):457-465.

25. Carlet J, Astagneau P, Brun-Buisson C, Coignard B, Salomon V, Tran B, Desenclos JC, Jarlier V, Schlemmer B, Parneix P, Regnier B, Fabry J, French National Program for Prevention of Healthcare-Associated Infections and Antimicrobial Resistance: French national program for prevention of healthcare-associated infections and antimicrobial resistance 1992-2008: positive trends, but perseverance needed. Infect Control Hosp Epidemiol 2009, 30(8):737-745.

26. Goldmann DA, Weinstein RA, Wenzel RP, Tablan OC, Duma RJ, Gaynes RP, Schlosser J, Martone WJ: Strategies to prevent and control the emergence and spread of antimicrobial-resistant microorganisms in hospitals. A challenge to hospital leadership. JAMA 1996, 275(3):234-240.

27. Degos L, Amalberti R, Bacou J, Carlet J, Bruneau C: Breaking the mould in patient safety. BMJ 2009, 338:2585.

28. World Health Organization: The evolving threat of antimicrobial resistance options for action. Geneva: WHO; 2012. http://whqlibdoc.who.int/ publications/2012/9789241503181_eng.pdf; accessed December 14, 2012.

doi:10.1186/2047-2994-2-1

Cite this article as: Carlet and Pittet: Access to antibiotics: a safety and equity challenge for the next decade. Antimicrobial Resistance and Infection Control 2013 2:1.

\section{Submit your next manuscript to BioMed Central and take full advantage of:}

- Convenient online submission

- Thorough peer review

- No space constraints or color figure charges

- Immediate publication on acceptance

- Inclusion in PubMed, CAS, Scopus and Google Scholar

- Research which is freely available for redistribution 